\title{
A study on the relationship of poverty with untouchability practices
}

-Nikhil Dongol

\begin{abstract}
Poverty is a complex and much contested social phenomenon. Different authors have defined poverty from various perspectives. The definition of poverty by the author determines how that particular mechanism developed by them tried to combat the phenomena or what the ethical conception of social justice is based upon. Townsend relied on absolute and relative perspective whereas Rawls envisage about the just society with difference principle. Sen focuses on the lack of ability to make choice as poor to develop capability approach. To this, Sangroula opines lack of access to commodities and development, and social exclusion as three deprivations thereby leading to poverty. This article bases its empirical research of the villages of Kavre and Ramechhap district on the above 3 deprivation to analyze the multidimensional approaches to poverty. This study aims to figure out whether poverty as a cause of untouchability practices through stratified random sampling of 34 individuals
\end{abstract}

Poverty is a complex and much contested social phenomenon. The word poverty comes from the old (Norman) French word poverté (Modern French: pauvreté), from Latin paupertās from pauper (poor). ${ }^{1}$ Poverty is usually measured as either absolute or relative looking from the traditional paradigm. Absolute poverty refers to a set standard as to minimum need to sustain a life which is consistent over time and between countries. First introduced in 1990, the income oriented approach was manifested through the widely known a dollar a day poverty line, measured absolute poverty by the standards of the world's poorest countries. The World Bank defined the new international poverty line as $\$ 1.9$ a day in 2015. This traditional definition of poverty is very far from reality and is very controversial. Each nation has its own threshold for absolute poverty line. The depth and intensity of poverty varies across the world and in any regional populations. Moreover, in the country like Nepal where properties are measured in land or in kind, this threshold may not be relevant.

${ }^{1}$ WALTER W. SKEAT, AN ETYMOLOGICAL DICTIONARY OF THE ENGLISH LANGUAGE, p.469 (Dover Publications Inc., 2005). 
Relative poverty views poverty as socially defined and dependent on social context, hence relative poverty is a measure of income inequality. This focus not only on minimum subsistence conditions, but also in the conditions to participate in activities that is customary in a specific society. In the absolute poverty perspective, subsistence is a key concept while the concept of deprivation is focused in a relative perspective. Though deprivation connotes a much broader concept than poverty, it might be used to define the poor more precisely. According to Townsend ${ }^{2}$ deprivation is the "[...] state of observable and demonstrable disadvantage relative to the local community or the wider society or nation to which and individual, family or group belongs".

Different authors have defined poverty in various perspectives. The definition of poverty determines how the particular mechanism tries to combat the phenomena or what the ethical conception of social justice is based upon. Or simply the authors have reflected their perspectives on it and tried to mitigate it. The works of Amartya Sen on the mechanisms of poverty and on issues related to economic development, have contributed to refine the conception of poverty of economists and international institutions. Rawls focus on the two inequalities factors: political or legal and socio economic inequalities. He termed as 'least advantaged' referring to poverty and his second principles emphasized greatest benefit to them. He focuses on basic freedom for all and fair equality of opportunities. ${ }^{3}$ The original position approach of the Rawls theory suggests, defining the most disadvantaged from the income perspectives both quantitative and qualitative, and are to be distributed under veil of ignorance. Opposed to Rawls, Sen replace the notion of capacity (capability) to measure inequalities.

Amartya Sen points out the absence of capacity to identify preference and making choice. ${ }^{4}$ Poverty is a deprived identity constructed in person by lack of rights necessary to build his/her capability of making informed choice of preference. ${ }^{5}$ Moreover, Sen proposes that the poverty does not rely only in an absolute or relative dimension, but in the absolute standard of living

${ }^{2}$ P Townsend, Deprivation, 16 Journal of Social Policy 125, p. 125 (1987).

3 JOHN RAWLS, A THEORY OF JUSTICE, p. 92 (Harvard University Press, England, 2005).

${ }^{4}$ Id, p. 2; Eguzki. Urteaga, Understanding poverty: A debate between John Rawls and Amartya Sen, Researchgate. p.269-286 (Jan 2012, 10:00), https://www.researchgate.net/publication/292411997_Understanding_poverty_A_debate_between_John_Rawls_and _Amartya_Sen.

$\overline{5}$ AMARTYA SEN, POVERTY AND FAMINES: AN ESSAY ON ENTITLEMENT AND DEPRIVATION, p. 3 (Oxford University Press, 2011). 
instead, that can be comprised in this way: an absolute deprivation in terms of a person's capabilities and a relative deprivation in terms of access to commodities, incomes and resources. ${ }^{6}$ The Senian approach is not income based as Townsend represented, it considers that the failure of someone to achieve a certain minimum of capabilities is intrinsically related with poverty.

Poverty as metaphor of the state of deprivations consists of degeneration of moral values on the part of rich people in the form of monopoly on income and rent seeking attitude. ${ }^{7}$ Poverty is saddening outcome of the deprivation of human potentiality of enjoying rights, social inclusion and access to resources for producing income as opined by Sangroula. Poverty is not a cause but an outcome of deprivation. To address the problem of poverty, the state of deprivation should be addressed. Sangroula discussed about three sets of deprivations which combine three situations that are simultaneously affecting the vector of a person lowering to a bottom line level:

a) Deprivation of entitlements to livelihood/ essential commodities ${ }^{8}$ and advantages,

b) An acute state of social exclusion (socially as well as politically) and

c) The absence of access to resources and opportunities to development.

The article tries to analyze the above set of deprivations to discuss the situations of so called Dalit in the two districts. This state of deprivations is the state of subordination in economic as well as socio-political sense or context.

"Fundamentally, poverty is a denial of choices and opportunities, a violation of human dignity. It means lack of basic capacity to participate effectively in society. It means not having enough to feed and clothe a family, not having a school or clinic to go to, not having the land on which to grow one's food or a job to earn one's living, not having access to credit. It means insecurity, powerlessness and exclusion of individuals, households and communities. It

\footnotetext{
${ }^{6}$ Tiago Mendonça dos Santos, Poverty As Lack Of Capabilities: An Analysis Of The Definition Of Poverty Of Amartya Sen, Federal University of Santa Catarina, p. 10 (2018), available at https://www.researchgate.net/publication/327381829

${ }^{7}$ YUBARAJ SANGROULA, RIGHT TO HAVE RIGHTS, p. 1(Lex \& Juris Publication Pvt. Ltd., 2018).

${ }^{8}$ See Sen, supranote 5 .
} 
means susceptibility to violence, and it often implies living on marginal or fragile environments, without access to clean water or sanitation"9

Truth is existential. Inequality in wealth and income is a fact because it exists and it can be seen. Poverty is a state established by deprivation of five cardinal freedoms of human life. They are ${ }^{10}$ :

1. Ahimsa (freedom against violence)

2. Aryogyata (freedom against diseases)

3. Asteya (freedom against absence or want)

4. Aparigraha (freedom against exploitation)

5. Amartwa (freedom against early or unnatural death

Legally speaking, poverty is a deprivation of the protected sphere and the vector of adequate living. ${ }^{11}$

Similarly, untouchability and discrimination are integral part of each other. Often, the ends of untouchability is discrimination while the ends of discrimination is untouchability. In a narrow sense, untouchability can be taken as a part of broad discrimination. Discrimination can take different form and state. In the context of world, race was taken as a major form of discrimination due to which ICERD defines "Racial discrimination" as

any distinction, exclusion, restriction or preference based on race, color, descent, or national or ethnic origin which has the purpose or effect of nullifying or impairing the recognition, enjoyment or exercise, on an equal footing, of human rights and fundamental freedoms in the political, economic, social, cultural or any other field of public life. ${ }^{12}$

Whereas in Nepal, caste was taken as a fundamental one and the act defines caste-based discrimination and untouchability ${ }^{13}$. The division of persons into four types to perform respective

\footnotetext{
9 Indicators of Poverty and Hungers, UNITED NATIONS (April 2, 2018, 8:01 AM) https://www.un.org/esa/socdev/unyin/documents/ydiDavidGordon_poverty.pdf accessed on 2/4/2018.

${ }^{10}$ See Sangroula, supranote 7, p. 18.

${ }^{11} I d$.

12 International Convention on the Elimination of All Forms of Racial Discrimination, art. 1, Dec.21, 1965,660 UNTS 195.

${ }^{13}$ Caste Based Discrimination and Untouchability (Offence and Punishment) Act, s. 4 (2068).
} 
service or profession was the crux of the Vedic Plan. It had in no sense an implication of "hierarchy" in societal position. The distinction was not based on the 'platform' of birth one had, but on the quality or capability s/he had gained by virtue of nature. Thus, it was very much possible to have a son/daughter of Sudra to be a Brahmin because of his/her role of teacher or intelligence and vice versa. It was equally possible for a son/daughter of a Brahmin to become a Chettri and vice versa. However, in the course of time, it was converted into vertical hierarchy and had a huge ramification.

To examine the emergence of the practice of untouchability from this analytical paradigm, it is essentially an outcome of the vested and monopolized interpretation of the custom or professional division of the people, which was originally created to "stabilize the function of society in harmony as it was necessary for the interpersonal relations of the member of the society.

\section{Foundation "Implications" of the Practice of Untouchability}

Monopolization of State Power: Groups of elites invented a hierarchical structure, which led certain groups to inferior castes incapable of exercising the rights participate in the governance processes.

Creation of a "Status -governed Personality": Untouchability is an instrument for maintaining status-quo of human personality for reinforcing hierarchical structure where, a person's personality is determined by his/her platform of birth. His/her rights and duties are determined by his/her being associated with birth station. The sole objective behind untouchability is to secure hierarchy of certain groups against others, so that they have unchallenged and unquestioned privileges.

Legalization of the exclusive privilege of hierarchical Superiority: The ostracization of one is necessary for other's exclusive privilege of absolutist power. The religion or belief of fatalism is created as a ground philosophy for untouchability.

Creation of service provider population for exclusive benefit or comfort of Elitist class: The untouchability helps to create a 'distinctly recognized' population, which is, based on the coined belief of fatalism, defined as a 'group to be ruled or providing service for privileged class. 
For all these objectives, the untouchability is supported by norms and values colored by religious interpretations. The concept of hierarchical form of caste was a result of Muluki Ain, 1854 enacted at the time of Junga Bahadur Rana which was against the volksgeist ${ }^{14}$ - common consciousness of the people at that time. This caste based untouchability is a repercussion of this law. However, the society has change into a different paradigm of untouchability practices. There are many laws ${ }^{15}$ to prohibit the untouchability practices and interpretation of the court ${ }^{16}$ has propounded much jurisprudence in favor of equality and equity. Supreme court on 2061 BS $^{17}$ has issues a certiorari to the government to formulate a separate law to address the whole aspects of caste and racial discrimination. With the mandate, Caste Based Discrimination and Untouchability (Offence and Punishment) Act, $2068^{18}$ was enacted which not only prohibit the doer or orderer but also penalized the acceptor, abettor as well as inciter. It has also made a list of prohibited bases ${ }^{19}$ under Section 4. Another important aspect of this law is that it had included both the public and private sphere under the ambit of law. However, the crime of caste based and racial discrimination is ever increasing in a modified manner. Moreover, $\mathrm{SC}$ issued a mandamus to formulate regulations to fulfill the holistic objective of the act. In international context, Nepal had ratified CERD on 30 January 1971, which stands as a milestone on the international step to elimination of the racial discrimination. Some of the perspective of the court can be found in the following jurisprudence:

\section{- Adv. Bimal Bishwokarma et al v. Government of Nepal and others ${ }^{20}$}

\footnotetext{
${ }^{14}$ Friedrich Karl von Savigny, Encyclopaedia Britannica (14 Jan, 2020, 11:54), https://www.britannica.com/biography/Friedrich-Karl-von-Savigny\#ref15572

${ }^{15}$ Universal Declaration of Human rights, arts. 1, 7, 16, Dec 10, 1948, 999 U.N.T.S. 171; International Convention on the Elimination of All Forms of Racial Discrimination, arts. 1, 2, 3, 4, 5, 6, 7, Dec 21, 1965, 660 UNTS 195; International Covenant on Civil and Political Rights, arts. 1(1)(2), 2(1)(2)(3), 6(1), 14(1), Dec 15, 1966, 999 UNTS 171; International Covenant on Economic, Social and Cultural Rights, arts. 3,6(1)(2),7(a)(b),9,10,11(1)(2),12(1),13(1)(2), Dec 16, 1966, 993 UNTS 3; UNGA res 52/111, World Conference against Racism, Racial Discrimination, Xenophobia and Related Intolerance (Durban Declaration or WCAR), 2001; CONST. of Nepal (2072), arts 18(2)(3), 19, 24, 255, 256 ; Human Rights Commission Act (2053); Racial discrimination and untouchability (crime and punishment) Act, sec 5,7 (2068); National Dalit Commission Act, (2074); Procedure for ending caste discrimination and untouchability and promoting Dalit rights, (2073)

${ }^{16}$ Man Bahadur Biswokarma v. HMG, (2049), NKP 2555; Dil Bahadur Bishwokarma v. HMG, (2062), NKP 1177; Adv. Ratna B. Bagchand et al v. OPMCM et al, (2061), NKP 3378.

${ }^{17}$ WN 46, Decision date: 2062/1/8

${ }^{18}$ It mentions ' No person shall be subjected to any form of untouchability or discrimination in any private and public places on grounds of his or her origin, caste, tribe, community, profession, occupation or physical condition".

${ }^{19}$ it includes grounds such as custom, usage, religion, culture, caste, lineage, community or profession.

${ }^{20}$ Adv. Bimal Bishwokarma etal v. GON and others, (2064), 2 NKP 7815
} 
The court accepted that the social equality as a cause of caste based discrimination leading to untouchability. The court had issued a mandamus to operate awareness campaign to eradicate the caste based discrimination.

\section{- Adv. Ratna Bahadur Bagchand etal v. HMG and others ${ }^{21}$}

The quantum of punishment may or may not be directly related to crime control. The importance of punishment to eradicate the untouchability practices is on one hand whereas the realization of the general public and society that all human beings are born free and equal is on the other hand. Therefore, the court issued a mandamus to take necessary action including formulating appropriate laws to fulfill the objectives of CERD, 1966 and Art. 11(4) of Constitution of Kingdom of Nepal, 2047.

\section{- Adv Ratna Bahadur Bagchand v. PM and Office of PM²}

The act of caste based discrimination and untouchability is against the equality among citizens and it obstruct the national upliftment by inviting social disorder. The court has taken into cognizance that mere law making could not help eradicate these practices. The court issued an mandamus to emphasize awareness enhancing objective based programs. Here. the lack of education is taken as a cause of untouchability practises.

\section{- Shyam Kumar Bishwokarma etal v. Nepal Government and others ${ }^{23}$}

The situation of untouchability, which stood as a societal stigma, cannot be completely eradicating by mere providing punishment to the offender. To this, gravity of the offense and the division it brought to the society, its present and future consequence to the future generations, and the effect to the social prestige of the offender after the punishment should be explicitly discussed to eradicate the offense from its roots. With the international obligations from CERD and to ease the legal remedy for the victims of caste based discrimination and untouchability, Court had issued a mandamus to the Nepal Government to formulate Caste based discrimination and untouchability (offense and punishment) regulation within 3 months.

\footnotetext{
${ }^{21}$ Adv. Ratna Bahadur Bagchand etal v. HMG and others, (2062), 2 NKP 7491

22 Adv Ratna Bahadur Bagchand v. PM an Office of PM (2062), 2 NKP 7499.

${ }^{23}$ Shyam Kumar Bishwokarma v. Nepal Government and others, (2073), 7 NKP 9636.
} 
Despite all these, the untouchability practices can still be found in the society. Therefore, we ought to look at the working definition indigent in context of societal perspective of Nepal. Law should be a means to an end rather than a game of elites popularly quoted in the words "Garib lai Ain, Dhani lai Chain". According to Roscoe Pound, we should 'look more for the working of law than for its abstract content'. The main purpose of law should be to eradicate the untouchability practices found in the society. For this, we ought to figure out the causes of untouchability practices.

\section{Poverty as an inequality}

The demand for justice is also a demand for equality. The phenomena of poverty lead us to reflect on the notion of justice. The application of the laws and regulations in force is not always sufficient to guarantee equity. The legitimacy of these laws and regulations does matter. And the practical aspect of the problem of poverty adds to the concern of legitimacy. Hagerstrom, a profound Scandinavian Realism philosopher opines that the term 'justice' represents, in reality, no more than a personal, highly-subjective evaluation of some states of affairs. ${ }^{24}$ Justice is a vague and a subjective concept. Max Weber's theory of scientific approach to law identified 'legal rational form' as a type of domination, not attributable to people but to abstract norms. ${ }^{25}$ Injustice is an objective fact, whereas justice is a perception. The common person looks for removal of injustice as a form of justice. ${ }^{26}$ Injustice could be said to be present if 3 things exists: i) Regressive status quo ii) Hierarchical structure of the society, and iii) Deprivation. As per the assumptions, the so called Dalits are placed in the lower class at the vertical hierarchical superstructure of the society and are deprived from the essential commodities like water, opportunities to development like education as well as a tendency to exclude from the society, thereby, leading to regressive status quo. Hence, the practice of untouchability is causing injustice to the so called untouchables.

Among the fundamental writings of $20^{\text {th }}$ century political philosopher, The Theory of Justice by John Rawls (1971) has suggested justice the determining criterion of institutions in a well-

\footnotetext{
${ }^{24}$ L.B. CURZON, JURISPRUDENCE, p. 169 (2 ${ }^{\text {nd }}$ edn, Cavendish Publishing Limited, 1998)

${ }^{25}$ DR. YUBARAJ SANGROULA, JURISPRUDENCE THE PHILOSOPHY OF LAW, p. 260 (Lex and Juris Publication Pvt. Ltd., 2018)

${ }^{26}$ See Sangraula, supranote 7, preface $\mathrm{xx}$
} 
ordered society. The well-ordered society is a society governed by two principles of justice conceived as equity: Firstly, the principle of equal basic freedom for all and secondly, the principle of fair equality of opportunities and the principle of difference. ${ }^{27}$ The first principle is a priority with respect to the second, which means that, in a well-ordered society, freedoms cannot be sacrificed, partially or totally, to a superior welfare or to reinforce equality of opportunities. The sacrifice of a particular freedom can only be justified by the extension of freedoms in general. His transcendental institutionalism approach to justice envisage for a perfectly just society, which could be achieved through difference principle. This led to affirmative action to dalit in each and every sectors of Nepal along with the provision in Nepali law ${ }^{28}$. His concept of distributive justice and was applied to the United States and many other countries but failed miserably. In light of its drawbacks, Amartya Sen opines on the idea of justice rather than the concept of justice. He is of the view on building capability of the individuals in regards of productivity, creativity, intellect and persistency. Simply, he viewed justice to make the individuals capable to make informed or right choice of preference.

The above mentioned about the role of state in eradication of the problem of untouchability. However, state, in its capacity, making law is not enough. Law and society are the two side of a same coin. Sociological School focuses on functional approach of law. It concerns the law in action. Lawyers are the law makers and state is only the announcer of those laws made from the society. Law as a social institution to satisfy social wants by giving effect to as much as we may with the least sacrifice, so far as such wants may be satisfied or such claims given effect by an ordering of human conduct thorough politically organized society. ${ }^{29}$ Rosceopound had used the term social engineering for recognizing and satisfying of human wants or claims or desires though social control; a more embracing and more effective securing of social interests; a continually more complete and effective elimination of waste and precluding of friction in

\footnotetext{
${ }^{27}$ See Rawls, supranote 3, p. 60.

${ }^{28}$ CONST. of Nepal (2072), art. 40, 42, 84(2), 86(1)(a), 255; National Dalit Commission Act (2074); Caste Based Discrimination and Untouchability (Offence and Punishment) Act (2068).

${ }^{29}$ ROSCOEPOUND, AN INTRODUCTION TO THE PHILOSOPHY OF LAW, p. 47 (Universal Law Publishing Co. Pvt. Ltd., 2006).
} 
human enjoyment of the goods of existence. ${ }^{30}$ His notion of law in book and law in action can be clearly seen in context of the untouchability practices.

\section{Looking for the solution}

The people belong to the so called lower class group had themselves tried to solve the problem of untouchability. Firstly, they convert into Christian Religion. The conversion, they think, it can change the whole mindset of the same peoples making it a new synthesis from the conflict of thesis and antithesis as analyzed by Marx. This can prevent them from social exclusion creating a new society in itself. Secondly, they went abroad in search of employment opportunities. This can make them entitlement to various commodities and life opportunities since they are economically sound enough. The trend of foreign employment in Nepal had not only attracted these so called dalits but also non-dalits which led to lack of manpower in the village, consequently, leading to the societal breakdown and most importantly, the untouchability practices. In most cases, the breakdown of the society is negatively connoted, however, in this context; it seems to be positive in eradicating it.

Thirdly, the stratification of the village into different strata has been also prevalent to mitigate the problem of untouchability. The dalit village and Tamang village was planned and constructed separately to build up different water canal, since, water touched by one is not usable to other. In this way, the common consciousness of the people is resulting in the slow decrease in the defects of the untouchability practices. Though these practices of separate water tap is widely found in other districts of Nepal like Dadelhdhura, Kanchanpur, Kailali etc to which applicant Adv. Ratna Bagchand et al filed a case, it is still regarded as a progressive step to stop being socially oppressed, financially exploited, politically neglected and dalit in term of labor.

\section{Untouchability redefined}

Untouchability is the institutions made by the elite class for which Marx calls it a superstructure. Today, the Nepalese society has in the verge of converting into Emile Durkheim's organic society, becoming more complex with the emergence of new institutions ${ }^{31}$ like the church and

\footnotetext{
${ }^{30} i d$.

${ }^{31}$ EMILE DURKHEIM, THE DIVISION OF LABOUR IN SOCIETY, p. 148 (Steven Lukes ed, Palgrave Macmillan, 2013)
} 
different local units. These units are more likely to regulate each and every aspects of public life even in the rural areas. For a law to be a living law as said by Elrich, there needs a prospect of economic analysis of law. The historical dialectic materialism could be analyzed in context of deprivation in relation to untouchability practices; however, the change in situation and emergence of new social institution has made it ineffective.

In regards to law, law is a dynamic process so that rules are constantly changed, created, and molded to suit particular situations. Law should possibly include the prospects of concept of welfare state as well. In Bhimeshwor VDC, there were three villages (Bhedagaun, Nayabari, Charuwa). Even if one village is connected with the transportation facility the other will automatically get access to the market. In this regard, government should take an initiative to provide subsidies to the vehicle in order that the people's right to be entitled to commodity is secured.

\section{Conclusion}

Basically, law should create a norm, most importantly, a legal norm. Not every norm is a legal norm; its content should be logically deducible from a presupposed basic norm (Grundnorm). Moreover, grundnorm of every legal system is derived, not logically but sociologically. Alternative method of creating norms is that of custom and is based on the superiority of what Hayek calls "spontaneous order" which is unplanned, undersigned and evolved. In this regard, the existence of a robust legal profession is a vanguard of the rule of law to create an environment of making a norm creating law. Deconstruction is not always the solution for improving the current condition of the peoples especially the untouchables. Therefore, the lawyers, lawmakers, and the interpretative organ of the state ought to address the state of deprivation among the peoples to discover new ways to mitigate the problems arising from the untouchability practices. 


\section{BIBLOGRAPHY}

\section{i. Books}

a. L.B. CURZON, JURISPRUDENCE ( $2^{\text {nd }}$ edn, Cavendish Publishing Limited, 1998)

b. YUBARAJ SANGROULA, JURISPRUDENCE THE PHILOSOPHY OF LAW (Lex and Juris Publication Pvt. Ltd., 2018)

c. EMILE DURKHEIM, THE DIVISION OF LABOUR IN SOCIETY (Steven Lukes ed, Palgrave Macmillan, 2013)

d. JOHN RAWLS, A THEORY OF JUSTICE (Harvard University Press, England, 2005)

e. ROSCOEPOUND, AN INTRODUCTION TO THE PHILOSOPHY OF LAW (Universal Law Publishing Co. Pvt. Ltd., 2006)

f. YUBARAJ SANGRAULA, CONCEPT AND EVOLUTION OF HUMAN RIGHTS: NEPALESE PERSPECTIVE (Kathmandu School of Law, 2005)

g. YUBARAJ SANGRAULA, JURISPRUDENCE; THE PHILOSOPHY OF LAW ORIENTAL PERSPECTIVES WITH SPECIAL REFERENCE TO NEPAL (Kathmandu School of Law, 2010)

h. YUBARAJ SANGRAULA, RIGHT TO HAVE RIGHTS (Lex \& Juris Publication Pvt. Ltd., 2018)

i. AMARTYA SEN, POVERTY AND FAMINES: AN ESSAY ON ENTITLEMENT AND DEPRIVATION (Oxford University Press, 2011)

\section{ii. Others}

a. A. K. SEN, A sociological approach to measurement of poverty: a reply to professor Peter Townsend. Oxford Economic Papers, v. 37, n. 4, 1985a.

b. ActionAid Nepal et. al, National Dalit Strategy Report, (prepared for National Planning Commission Nepal) Kathmandu, 2002

c. Eguzki. Urteaga, Understanding poverty: A debate between John Rawls and Amartya Sen, Researchgate. p.269-286 (Jan 2012, 10:00), https://www.researchgate.net/publication/292411997_Understanding_poverty_A_debate_ between_John_Rawls_and_Amartya_Sen

d. G.R. Tripathi, Socio-economic condition of landless people in Nepal, 2005 
e. Indicators of Poverty and Hungers, United Nations, 1998, available at https://www.un.org/esa/socdev/unyin/documents/ydiDavidGordon_poverty.pdf accessed on $2 / 4 / 2018$.

f. Kamal Raj Thapa, 'The Cabbage wen know as Jurisprudence: A Composition of One Layer upon Another', vol. 2, Issue 1, 2013

g. Luma Singh Bishwakarma, 'Jurisprudential Analysis of concept of justice', Nepal Law Review, Vol. 18, No. 1 and 2, 2005

h. P Townsend, Deprivation, 16 Journal of Social Policy 125, p. 125 (1987)

i. Skeat, Walter W., An Etymological Dictionary of the English Language, Dover Publications Inc., New York, 2005.

j. Tiago Mendonça dos Santos, Poverty As Lack Of Capabilities: An Analysis Of The Definition Of Poverty Of Amartya Sen, Federal University of Santa Catarina, p. 10 (2018), available at https://www.researchgate.net/publication/327381829 